\title{
Los Soldados, sus Jefes y el Estado: La Construcción de la Obediencia en el Ejército de Línea (Argentina, 1862-1882)*
}

\section{Lucas Codesido Marzoratti}

\begin{abstract}
Docente e investigador de la Universidad Nacional de la Matanza (Argentina). Correo electrónico: Lucas_codesido@yahoo.com.ar. El autor es Doctor en Historia Universidad Nacional de La Plata (Argentina). Entre sus publicaciones recientes tenemos: "Delincuentes, mercenarios y ciudadanos. La política militar de Alsina y el avance de la frontera (1874-1877)", Antigua Matanza, Revista de Historia Regional, Junta de Estudios Históricos de La Matanza Vol. 3 No. 1 (2019) y "1880. Guerra y política en Buenos Aires. Michel Foucault y la revolución de 1880” En Cuadernos de Marte No. 13 (2017). Entre sus temas de interés está: El papel de las fuerzas armadas durante la construcción del Estado Argentino.
\end{abstract}

Recibido: 30 de marzo de 2019

Aprobado: 8 de mayo de 2019

Modificado: 24 de mayo de 2019

Artículo de investigación científica

DOI: http://dx.doi.org/10.15648/hc.35.2019.7

Este artículo forma parte del proyecto de investigación "La construcción de la obediencia en el ejército de línea (Argentina, 1862-1882)", financiado con recursos propios.

Esta publicación está bajo una licencia Creative Commons Reconocimiento-NoComercial 4.0 
Los Soldados, sus Jefes y el Estado: La Construcción de la Obediencia en el Ejército de Línea (Argentina, 1862-1882)

\title{
Resumen
}

En este trabajo se examinan algunas prácticas que hacen al funcionamiento de las fuerzas armadas de la Nación en el período 1860-1880. Se explora la composición de las fuerzas de línea y el carácter penitenciario que asumía el servicio militar en las tropas nacionales en el contexto de la militarización de la vida política argentina de la segunda mitad del siglo XIX. Nos interrogamos acerca de los mecanismos que se ponen en juego en las relaciones entre soldados y oficiales en función de este carácter punitivo que representaba la propia existencia del Ejército de Línea.

Palabras clave: ejército argentino, siglo XIX, servicio militar, fuerzas armadas.

Soldiers, their heads and the state: the construction of obedience in the line army (Argentina, 1862-1882)

\begin{abstract}
This paper examines some practices carried out to the military forces training of the Nation in the period 1860-1880. It is explored the configurations of the line forces and the penitentiary character assumed by military service within national troops in the militarization of Argentine political life context during the second half of the 19th century. We question about the mechanisms brought into play in the relations between soldiers and officers based on this punitive character that represented the very existence of the Army of Line.
\end{abstract}

Keywords: argentine army, 19th century, military service, armed forces.

\section{Os Soldados, Os Chefes E O Estado: A Construção Da Obediência No Exército De Linha (Argentina, 1862-1882)}

\section{Resumo}

Este artigo examina algumas práticas que fazem o funcionamento das forças armadas da nação no período 1860-1880. A composição das forças da linha e do caráter penitenciário que o serviço militar assumiu nas tropas nacionais no contexto da militarização da vida política argentina na segunda metade do século XIX é explorada. Nós nos questio- 
namos sobre os mecanismos que são colocados em jogo nas relações entre soldados e oficiais baseados neste caráter punitivo que representou a própria existência do Exército de Linha.

Palavras-chave: exército argentino, século $19^{\circ}$, serviço militar, forças armadas.

\section{Les Soldats, Leurs Chefs Et L'état: La Construction De L'obéissance Dans L'ar- mée De Ligne (Argentine, 1862-1882)}

\section{Résumé}

Ce travail examine certaines pratiques qui font le fonctionnement des forces armées de la nation dans la période 1860-1880. Il examine la composition des forces de ligne et le caractère pénitentiaire du service militaire dans les troupes nationales dans le contexte de la militarisation de la vie politique argentine de la seconde moitié du XIXe siècle. Nous nous interrogeons sur les mécanismes qui sont en jeu dans les relations entre soldats et officiers en raison de ce caractère punitif qui représentait l'existence même de l'armée de Ligne.

Mots clés: armée argentine, XIXème siècle, service militaire, forces armées

\section{INTRODUCCIÓN}

"En estos tiempos, no obstante admirar el pueblo el valor y las glorias del Ejército, casi nadie quería ingresar en la carrera militar. Pues los batallones, cuerpos, regimientos y demás instituciones de esta naturaleza eran considerados por nuestros ciudadanos como cuerpos de corrección o establecimientos de punición. Por consiguiente, yo sabía con seguridad que la negativa de mi familia la tendría en masa; no había que pensar en solicitar el beneplácito de mis padres"'.

José Silvano Daza, uno de los primeros egresados del Colegio Militar de la Nación, evoca en sus memorias el paso por las aulas del colegio militar

1 José Daza, Episodios militares (Buenos Aires: Librería La Facultad, 1914), 241. 
en sus primeros años de existencia durante la década de 1870. Aquella visión carcelaria proyectada sobre las fuerzas de línea era compartida por quienes hacían la política militar, por los jefes, los oficiales, por los mismos soldados, sus familiares y personas cercanas que experimentaban la actividad militar de aquellos como un castigo en sí mismo -y no tanto como actividad producto de un castigo si había sido destinado-, muchas veces injusto. El servicio militar aparecía como una condena desproporcionada en relación a la magnitud de la falta cometida, si es que la hubo, y sin efectos reparadores o de "redención social" para aquel que lo cumpliese en tiempo y forma, pues no se percibía que el tiempo ni las formas sean respetados una vez que se ingresaba a servir en la tropa de línea.

Una enorme cantidad de peticiones escritas por parientes, empleadores y conocidos de los destinados llegadas al Ministerio de Guerra y Marina ${ }^{2}$, y el tenor de esos mensajes suplicantes de "gracia", justicia, revisión de penas, o sobre los que por estar en situación de "cumplidos" deben ser dados de baja, han constituido durante nuestra investigación una buena muestra donde apreciar aquella visión punitiva que pesaba sobre los componentes de la tropa de línea ${ }^{3}$. Hemos constatado que la misma utilización del vocablo "cumplido", en las comunicaciones militares tenía esa doble acepción, a veces se refería al cumplimiento del servicio -el contrato- de enganche- y otras al cumplimiento de la condena por la cual el soldado había sido destinado.

La escasa afluencia de postulantes a la carrera de oficial en los primeros años, se relacionaba con la evocación que hace José Daza -uno de aquellos primeros aspirantes- acerca de la consideración que la sociedad de su tiempo tenía sobre la carrera militar. La idea de que las unidades militares

2 Pueden consultarse en el Archivo del Estado Mayor General del Ejército, las carpetas denominadas "Política interna y causas" en la colección del archivo Organización Nacional, 1860-1880. En EMGE, Servicio Histórico.

3 Tesis doctoral: Codesido, L. (2016). Armar al Estado, construir la Nación. La nacionalización de las fuerzas armadas en la Argentina y su vinculación con el proceso de construcción del Estado nacional”. Tesis de Doctor en Historia. La Plata. Fahce/UNLP. Incluso aparecen registros de personas que piden porque algún pariente cercano sea enviado al servicio militar como medida punitiva: Un oficial eleva la solicitud para que un joven sea recibido en la fuerza a raíz de "los frecuentes desórdenes que Robles comete sin que le sea posible a su señora madre contenerlo, ésta ha firmado la requisición de que hago mérito". EMGE, Organización Nacional, Caja 56, mayo-junio de 1875, Folio 31, documento 16826. 
eran "cuerpos de corrección o establecimientos de punición” tenía su correlato en la composición social de la tropa. La gran presencia de individuos destinados por delitos comunes a servir en esos cuerpos en donde también iban a parar los "vagos y malentretenidos", o los infractores a la ley de enrolamiento de la Guardia Nacional y otros tantos, llevados por la fuerza de la arbitrariedad en la figura del "contingente", daban un contenido real a esas representaciones ${ }^{4}$.

En el contexto de militarización de la vida política sobre el que acontece esta realidad en los cuerpos armados del Ejército, también aparecen diversos proyectos reformistas tendientes a la profesionalización de las fuerzas armadas, aunque la propia urgencia de la guerra en la sociedad dejaba poco espacio para las grandes reformas ${ }^{5}$. La creación del Colegio Militar de la Nación al iniciar la década de 1870 se vincula con el propósito del presidente Sarmiento y su vocación de separar al ejército de las luchas facciosas mediante su profesionalización ${ }^{6}$. Esos intentos tendientes a la centraliza-

4 Cabe recordar que la Guardia Nacional en Argentina había sido definida por el artículo 21 de la Constitución nacional como reserva del Ejército de Línea, que podía ser movilizada cuando lo reclamaran circunstancias graves, tales como conmociones internas o guerra exterior. Estaba conformada por todos los hombres (argentinos) mayores de edad, entre 18 y 50 años. La Constitución acordaba a las provincias el nombramiento de los oficiales de la Guardia Nacional y el régimen disciplinario que regía en ella. Una vez movilizadas, cambiaba su dependencia de la órbita provincial a la nacional y su situación se tornaba idéntica a la de la tropa de línea. En la práctica la regla que establecía pasar a la órbita nacional a la Guardia Nacional una vez movilizada no fue muchas veces interpretada de ese modo por los gobiernos provinciales y fue un motivo de disputas entre la Nación y las provincias hasta el año 1880. Sobre la Guardia Nacional y el principio de ciudadanía armada véase: Hilda Sabato "El ciudadano en armas", Entrepasados, Revista de Historia, Buenos Aires, año 12 No. 23 (2002): 149-169; Flavia Macías, Hilda Sábato, "La Guardia Nacional: Estado, política y uso de la fuerza en la Argentina de la segunda mitad del siglo XIX”, en PolHis, Año 6 No. 11 (2013):70-81; Flavia Macías, "El deber de enrolarse y el derecho a votar. Reflexiones en torno a la ciudadanía armada y el sufragio en Argentina, 1863-1877”, Revista de Indias, Vol. LXXVI No. 266 (2016): 233-258.

5 Este proceso de militarización de la vida política argentina ha sido abordado, entre otros autores, por Hilda Sábato y Eduardo Míguez: Eduardo Míguez, "Guerra y Orden Social en los orígenes de la Nación argentina, 1810-1880”, anuario IEHS No. 18, Tandil (2003): 17-38; Hilda Sábato "El ciudadano en armas, 149-169, Hilda Sábato, A. Lettieri, La vida política. Armas, votos y voces en la Argentina del siglo XIX (Buenos Aires: FCE, 2003); Hilda Sábato, "Resistir la imposición, Revolución y ciudadanía y república en la Argentina de 1880", Revista de Indias, Vol. LXIX, No. 246 (2009):159-182. También lo hemos desarrollado en otro trabajo Lucas Codesido, "Militarización de la política y política de guerra en el Ejército argentino (1870). Faccionalismo, lealtades políticas y mecanismos de promoción de los jefes y oficiales durante el proceso de construcción del Estado", Historia Caribe, Vol. IX No. 24 (2014):131-161.

6 El objetivo del poder político -representado en la figura de Sarmiento- era el de separar a los militares profesionales de la política, por su especialización en las técnicas de manejo de la violencia, y a su vez reforzar su papel de sujeción a los fines estipulados por la propia política. Los proyectos de 
ción del poder militar de la Nación sobre las provincias se inscriben a su vez en el proceso de construcción del Estado nacional. Un Estado que no avanza únicamente sobre la sociedad civil $^{7}$ sino que será el resultado de una dinámica que plantea trasladar el poder desde la periferia hacia el centro, de las provincias a la Nación ${ }^{8}$.

Nuestra investigación se propone, en el breve espacio que permite este artículo, dar cuenta de algunos mecanismos que se ponen en juego a la hora de hacer posible las relaciones de autoridad y subordinación en las tropas que responden a la Nación. Además, intentamos contextualizar esos vínculos, trazando un posible correlato entre los datos disponibles acerca de los modos de reclutamiento de quienes conforman esos cuerpos armados y las representaciones sociales que giran en torno a ellos. Más adelante examinamos la diferencia entre los soldados viejos y soldados nuevos, en relación con las posibilidades de construcción de las relaciones de autoridad hacia el interior de la unidad. También analizamos el papel de los jefes militares y sus distintas estrategias para conseguir la subordinación de la tropa nueva. Ello en función del peligro que representaba, incluso para la propia existencia de la fuerza de línea, el equilibrio entre la incidencia de los nuevos reclutas destinados al servicio de las armas y el influjo de los soldados veteranos.

\section{Negociar LA ObEDiENCIA}

'Yo puedo decir que nadie há derramado una lágrima por mí; que nadie há sido violentado ni maltratado por mí; que en estas fronteras ya no se ponen grillos, ni se aplican carreras de baqueta, ni se dan tormentos, como lo prueban mis repetidas órdenes sobre el particular, ni se hacen fusilamientos en masa como antes

reforma impulsados durante la gestión de Sarmiento fueron el Código Militar, la ley de reclutamiento de 1872 -que habilitaba el sorteo universal para todos los ciudadanos-y la puesta en funcionamiento del Colegio Militar. De ellos, el Código Militar nunca se sancionaría -deberá esperar hasta fines de siglo-, la ley de reclutamiento se aprobaría en 1872 pero el sistema de sorteo universal que disponía nunca se puso en práctica efectivamente -también tuvo su dilación hasta fin de siglo-, y por ello el Colegio Militar, concebido como academia de formación de oficiales será la única de esas instancias llevada a la práctica desde principios de la década de 1870.

7 Oscar Oszlak, La formación del Estado argentino (Buenos Aires: Editorial de Belgrano,1982).

8 Beatriz Bragoni y Eduardo Míguez, Un nuevo orden político. Provincias y Estado Nacional, 18521880 (Buenos Aires: Biblos, 2010). 
sucediera...Y puedo decir algo más, que gozo de la consideración pública, del respeto de mis subalternos, del cariño de mis soldados...

Yo puedo decir que bandidos famosos contra quienes nadie podía, que eran el azote de las poblaciones y se burlaban de la justicia, hán venido á ampararse de mí, y que utilizándolos para la seguridad de la frontera, los hé neutralizado á la vez para el mal"'.

Así razonaba Lucio V. Mansilla acerca de los elementos que pone en práctica como jefe de frontera para sujetar la obediencia de sus subalternos. Sus palabras eran parte de un alegato de defensa ante el Ministro de Guerra Gainza frente a la acusación por una supuesta orden de fusilamiento ordenada contra dos soldados que desertaron bajo su mando. En esa defensa de su inocencia, la "consideración pública" el "respeto" de sus subalternos y el "cariño" de sus soldados aparecen entre los argumentos que ponía en juego al momento de volver más verosímil la negación de su responsabilidad por aquellas ejecuciones.

Los modos de enfrentar el problema de la deserción, uno de los mayores dentro de las unidades de Línea, y la gran calamidad en los ejércitos de todos los tiempos, colocaban en un primer plano las diversas modalidades de relación entre el jefe y la tropa ${ }^{10}$. Hemos encontrado en la documentación

9 Carta de Lucio V. Mansilla al ministro Gainza (del 4 de febrero de 1870) en la que hace su descargo alegando inocencia luego de enterarse que se le ha iniciado un sumario interno por estar acusado de haber ordenado el fusilamiento de dos soldados de los cuerpos que manda en la frontera sin haber dado cuenta al ministerio de guerra. AGN, Sala VII, Fondos del Museo Histórico Nacional, Legajo 36, año 1870 , documento 6267.

10 Sobre la deserción en los ejércitos europeos Francisco Andújar Castillo, Ejércitos y Militares en la Europa Moderna (Madrid: Editorial Síntesis, 1999). En los ejércitos de la independencia Alejandro Rabinovich, "El fenómeno de la deserción en las guerras de la revolución e independencia del Río de la Plata: 1810-1829", Estudios Interdisciplinarios de América Latina y el Caribe, Tel Aviv, Vol. 22, No. 1. (2011); Alejandro Morea, "Las deserciones en el Ejército Auxiliar del Perú durante las Guerras de Independencia en el Río de la Plata, 1810-1820", Una aproximación cualitativa. Americanía: Revista de Estudios Latinoamericanos (2015): 159-197. En las sociedades de frontera Leonardo Canciani, "Resistencias a la obligación de armarse. Reclutamiento y servicio militar en la Guardia Nacional de frontera", Memoria americana, Cuadernos de Etnografía, Vol. 22, No. 1, (2014): 33-63; José Miguel Larker, "Las deserciones en la línea de frontera: Formas de resistencia y conflictividad social en la campaña santafesina (1855-1895)" (Ponencia: X Jornadas Interescuelas/Departamentos de Historia, Rosario, 2005). 
y testimonios del período cantidad de referencias acerca del fenómeno de la deserción, de lo relativamente accesible que resultaba para aquellos que decidían evadirse del servicio militar, abandonar su puesto y encaminarse hacia una nueva vida lejos del control de las autoridades militares ${ }^{11}$. Eran muchos los motivos que podían justificar la huida hacia una nueva vida de libertad, todos relacionados con la precariedad de una existencia que giraba en torno a la escasez de alimentos, de ropa y calzado adecuado, o de la paga que nunca llegaba en tiempo y forma. A ello se añadía la arbitrariedad de los jefes a quienes estaban obligados a responder, sus modos de ejercer la autoridad y administrar los castigos disciplinarios ${ }^{12}$. Se debe recordar que el ejército argentino no contaba con un código militar propio, no se había sancionado ninguno desde la independencia, y la justicia militar se aplicaba a partir de diversas adaptaciones de las Ordenanzas Militares de Carlos III, sancionadas en 1768 para las fuerzas reales, que debían ser reinterpretadas y ajustadas para ser aplicadas en un sistema republicano ${ }^{13}$. Algunas voces, como las del coronel Álvaro Barros en 1872, señalaron la contradicción entre el espíritu de esa legislación española añeja a la que se recurría cuando había que justificar las prácticas de la justicia castrense y el avance de las instituciones del sistema republicano ${ }^{14}$. En una tesis doc-

11 "Los desertores, si son prendidos, son destinados como castigo a un cuerpo de línea; pero son pocos los que se prenden; un gaucho bien montado ganando las grandes llanuras es casi inasible; en cualquier estancia encuentra una hospitalidad discreta. La burguesía acomodada comprende perfectamente -y mejor que la aplicación que ella misma hace de las leyes- que ese hombre tiene razón al sustraerse mediante la fuga, a un suplicio inicuo e intolerable". Artículo de Alfredo Ebelot, publicado en la revista francesa Revue des Deux Mondes (1877). Alfredo Ebelot, Recuerdos y relatos de la guerra de fronteras.

12 Los jefes de cada cuerpo del Ejército de Línea disponían de amplia libertad para disponer castigos ejemplares a los indisciplinados. Más que para sancionar al delincuente, las penas servían para "moralizar" al resto de la tropa. Por ejemplo, una orden del día dictada por el jefe del regimiento $6^{\circ}$ de línea, movilizado en Gualeguay durante la campaña contra el jordanismo en 1871, disponía que: "Artículo 1. Todo soldado que robare de un real arriba, la primera vez será castigado con 8 días de estaqueada y 6 meses de prisión debiendo hacer la limpieza del cuartel diariamente con un letrero en la espalda y otro en el pecho, donde se verá escrito por LADRÓN. La segunda vez será sometido á un consejo de guerra y pasado por las armas si el robo fuera de consideración”. En EMGE, Servicio Histórico, Regimiento $6^{\circ}$ Infantería de Línea, Órdenes Generales y del Cuerpo, Orden del Cuerpo del 13 de marzo de 1871, pp. 24-25.

13 Lucas Codesido, "Las Ordenanzas Militares de Carlos III en la justicia militar argentina: Segunda mitad del siglo XIX", En Revista Contemporânea, Dossié Historia \& Literatura. Núcleo de Estudios Históricos, Universidade Federal Fluminense, Brasil, Ano 3, Vol. 2, No. 4 (2013): 2-23.

14 Álvaro Barros, Fronteras y territorios federales de las pampas del sur (Buenos Aires: Hachette, 1975), 84. El texto original es de 1872. 
toral de 1875, defendida en la facultad de ciencias médicas de la UBA, el aspirante a doctor, Francisco Castellanos asociaba, en palabras un tanto irónicas, la inexistencia de un código militar con la necesidad de "seguir dando palos" a los soldados:

"Estraño es que una ordenanza, un Código militar, no se haya confeccionado todavía con el objeto de limitar los castigos de que tanto se abusa, particularmente por los principiantes en la carrera. Recuerdo que en un ejercicio que hacía un batallón, un soldado cometió una falta, muy leve, se equivocó, en vez de hacer tal maniobra, hizo otra: esto fue suficiente para que en el momento su jefe le lanzára una estocada que trajo la muerte del individuo. Como ser intelectual, el soldado es susceptible de educarse, enséñesele que aprenderá, y si entonces comete faltas aplíquensele medidas tendentes á reformar la moral del individuo, que con palos y estocadas destruimos la materia sin conseguir el objeto que deseamos" $"$.

La percepción de injusticia con la que podía ser vivida por los propios soldados aquella exigencia de tributar disciplina y obediencia en tales condiciones, es la que nos condujo a examinar las conductas de quienes permanecieron en sus puestos. Este examen se propone en una dirección similar de las nuevas investigaciones acerca del fenómeno del caudillismo y las redes de poder de tipo clientelar ${ }^{16}$. Trabajos que al examinar los modos de relación entre los caudillos y sus seguidores empiezan a otorgar un mayor peso a las decisiones y motivaciones de los actores subalternos a la hora de analizar la construcción del poder surgido de esa vinculación. A ello se sumaba la construcción del "carisma" del caudillo que lideraba la partida, desde una perspectiva que hace foco en la percepción que tenían los gauchos seguidores acerca de su líder ${ }^{17}$. Para comprender los rasgos distintivos de esa trama de relaciones hemos llevado a cabo una exploración en la

15 Francisco Castellanos, "Hijiene del Soldado en Guarnición" (Tesis para el Doctorado, Facultad de Ciencias Médicas, Imprenta especial para obras de Pablo Coni, Buenos Aires, 1875), 43-44.

16 Noemí Goldman y Ricardo Salvatore, Caudillismos rioplatenses. Nuevas miradas a un viejo problema (Buenos Aires: Eudeba, 1998).

17 Ariel De la Fuente, Los hijos de Facundo (Buenos Aires: Prometeo, 2007). 
que entran en juego elementos que giran en torno de la relación entre tipos de conducta y sus representaciones examinando el tipo de cultura que las atraviesa $^{18}$. Tal como hemos afirmado antes, se ha podido notar a lo largo del trabajo que la visión proyectada desde los distintos grupos de la sociedad acerca de la condición de ser soldado de tropa en aquel tiempo jugaba un papel importante ${ }^{19}$. Habitualmente asociada con la idea del castigo, el escarmiento dado a alguien por cierta condición antisocial más que con una ocupación que pudiese ser elegida como profesión, o simplemente optada ocasionalmente entre otras. La idea de ocuparse como soldado de tropa en el ejército estaba asociada menos con la voluntad propia del soldado que con algún tipo de decisión ajena.

Según hemos podido encontrar en la documentación disponible, el perfil social de los actores subalternos de las fuerzas de Línea en su mayoría comparte condiciones similares a las del gaucho pobre que se plegaba a la montonera. Las unidades del ejército no se distinguían fácilmente de aquellas milicias irregulares identificadas por la figura de su jefe ${ }^{20}$.

Considerando la complejidad de aquella trama cultural atravesada por el fenómeno de la militarización hemos estimado que en lugar de preguntarnos por el fenómeno de la deserción y sus motivos nos parece más revelador tratar de interrogarnos acerca de los mecanismos que hacían que los soldados de tropa y oficiales subalternos continuaran en servicio a pesar de los ejemplos "desmoralizadores de toda disciplina” recurrentes

18 En este punto seguimos el trabajo de Clifford Geertz, entendiendo que la cultura "no es una entidad, algo a lo que puedan atribuirse de manera causal acontecimientos sociales, modos de conducta, instituciones o procesos sociales; la cultura es un contexto dentro del cual pueden describirse todos esos fenómenos de manera inteligible" Clifford Geertz, La interpretación de las culturas (Barcelona: Gedisa, 2003).

19 Siguiendo a Geertz, esa consideración formaba parte del "sentido común" de la sociedad en esta época: "los antropólogos disertan a menudo sobre complejidades conceptuales que presentan como hechos culturales por su incapacidad para comprender que gran parte de lo que sus informantes les dicen, por extraño que pueda sonar a oídos cultivados, debe entenderse literalmente". Clifford Geertz, Conocimiento local, Ensayo sobre la interpretación de las culturas (Barcelona: Paidós, 111).

20 Algunos testigos de su tiempo describían las unidades del Ejército de Línea como "montoneras con música", donde la existencia de la banda militar con sus toques de marcha figuraba ser lo único que diferenciaba a simple vista a esas fuerzas militares de una fuerza montonera. Prudencio Arnold, Un Soldado Argentino. Vida militar del Coronel de la Nación Prudencio Arnold (Rosario: Casa Editora "La Argentina", 1893). 
de aquellos individuos que huyen de los piquetes, guarniciones, fortines y fuerzas en campaña ${ }^{21}$.

\section{REClutamiento: LA TROPA}

Una característica social de la política militar del siglo XIX es que se trasladaba hacia el interior de las organizaciones militares las divisiones propias de la estructura social. Por ello los modos en que se realizaba la incorporación de nuevos cuadros al ejército en formación variaban en forma substancial de acuerdo con la distancia social que existía entre la tropa y el cuerpo de oficiales, desde la época de los ejércitos de la independencia ${ }^{22}$.

El reclutamiento de la tropa tenía -en teoría- las características del voluntariado. Los soldados firmaban contrato por dos, cinco y hasta 8 años. A estos se agregaban los "destinados" por crímenes o delitos comunes, a quienes desde los tiempos de la colonia se recurría para cubrir las vacantes que se producían en las unidades ${ }^{23}$. En la práctica las dos categorías no se distinguían muy bien. Por medio del enganche se contrataban voluntarios que quieren sumarse a la carrera de las armas. El método seguido era el de la "comisión”, una institución que funcionaba en España y se perfeccionaba desde el siglo XVI, que consistía en el encargo a un oficial -provisto del despacho para realizar la comisión- de reclutar un cierto número de voluntarios en un territorio. Por lo general este oficial actuaba como de-

21 Ignacio Fotheringham relata en sus memorias una lista de revista pasada por el entonces coronel Roca antes de la batalla de Santa Rosa luego de una larga marcha: "Una tarde, un poco antes de llegar a La Dormida, hizo un calor intenso y todo el día se marchó sin probar bocado. Yo creo que desertaron más de doscientos y aún me quedo corto. Iba silenciosa la columna. El silencio del cansancio y el aburrimiento. (...) ese silencio me permitía oír al coronel Roca que andaba averiguando personalmente las novedades. Cuenca había contestado: -Faltan sesenta. Y el $2^{\circ}$ de Arguello, que precedía al mío en la marcha, confesó: -Faltan ochenta, y echó tan colosal Cabronnada el señor coronel que dije yo entre mí: "Pongámonos en guardia". Llegó, malhumorado, desagradado, y: -Qué novedades. -Ninguna, señor. (...) Tanto era mentira mi información, que faltaban por lo menos cuarenta. Roca dijo entonces: -Al fin he hallado un batallón en regla. Y yo, con el tupé del caso; gracias”. (1999 [1909 edición original], pp.319-320).

22 Alejandro Rabinovich, Ser soldado en las guerras de independencia. La experiencia cotidiana de la tropa en el Río de la Plata, 1810-1824 (Buenos Aires, Ed. Sudamericana, Colección Nudos de la historia argentina, 2013).

2331 de octubre de 1862, decreto: "se determina el modo en el que los vagos y delincuentes serán destinados al servicio de armas en el ejército de línea” Ercilio Domínguez, Colección de Leyes y Decretos Militares (Buenos Aires: Compañía Sudamericana de Billetes de Banco.1898), 205. 
legado de alguien de mayor rango a cargo de dicha comisión. El oficial iniciaba su labor propagandística utilizando diversos medios y señuelos con el fin de atraerse el mayor número de hombres posibles a la unidad que más tarde él mismo mandaría en el campo de batalla. El gobierno a veces se valía de intermediarios, caudillos locales o autoridades políticas encargadas de ofrecer los contratos en los que se pagaba en efectivo una suma al comenzar el servicio y el resto al concluirlo. En la práctica el enganche aparecía muchas veces como una forma de voluntariado forzoso al cual eran llevados al servicio de armas quienes eran mal vistos por el juez de paz u otros sujetos sospechosos a los ojos del comisario, o simplemente individuos sin trabajo, que bajo amenaza de ser "destinados" eran obligados a tomar el contrato de enganche. Pues para incorporar a estos últimos además se podía recurrir a las disposiciones acerca de los "vagos y malentretenidos" que deambulaban por las ciudades y campaña siendo destinados -ya no enrolados- al ejército por su condición de individuos perjudiciales para la sociedad. El soldado enrolado por contrato prestaba juramento de servicio y a cambio cobraba un adelanto de la paga como señal de la futura soldada que debía recibir regularmente. Al finalizar su contrato y recibir la baja el soldado debía percibir el resto de la cuota establecida en el contrato de enganche.

Otro modo de reclutar hombres para el ejército fue el de contratar soldados mercenarios en el extranjero. Durante el gobierno de Mitre en la década de 1860 hubo comisiones especiales que se trasladaron a Europa para completar el déficit de voluntarios dentro del país. Desde 1861 Hilario Ascasubi y Rufino Varela actuaron en Francia, y en Italia Eduardo Calvari ${ }^{24}$.

Otra figura legal que aparece en la composición de la tropa es la del "personero". Este será un sustituto para aquellos que dispongan de medios económicos suficientes y quieran evitar el servicio militar poniendo un reemplazante a cambio de una suma de dinero en efectivo. La figura del personero aparece en forma frecuente en tiempos de movilización general

24 El último contingente europeo llegó a principios de 1868 destinado a custodiar la frontera con el indígena. El sistema demostró ser un fracaso para aquellos objetivos iniciales de reclutar profesionales por lo que simplemente derivó en conseguir individuos aptos para el servicio. Este último propósito tampoco fue un éxito debido a la poca cantidad de reclutas obtenidos. 
de la Guardia Nacional. Los personeros serian en su mayoría extranjeros o criollos pobres que estaban librados del servicio de la Guardia Nacional por no figurar en las listas de enrolados y no tener una ocupación estable, eran atraídos a servicio militar por la remuneración de 5000 pesos que corrían a cargo del contratante.

Otra importante provisión de reclutas en este período proviene de los prisioneros tomados en las guerras civiles. La documentación del Ministerio de Guerra y Marina nos muestra que en el período que analizamos (18611882) en todos los conflictos armados el Ejército Nacional incorporó un importante número de individuos que fueron condenados al servicio de las armas luego de formar en las filas del enemigo derrotado ${ }^{25}$.

Una figura que aparece durante todo este período relacionada con el reclutamiento forzoso es la del "contingente" de reclutas enviados al servicio militar. El contingente se enuncia como una cierta cantidad de soldados que solicita el gobierno nacional a los gobiernos de provincia para completar las plazas del Ejército de Línea. En teoría los contingentes deben componerse de guardias nacionales, es decir ciudadanos argentinos o "hijos del país" como establecen las disposiciones sobre esta figura. Sin embargo en la práctica también los extranjeros serán incluidos en el contingente, pues a la hora de recomendar las formas en que se puede llenar la cantidad de hombres requerida en las disposiciones oficiales se recomienda recurrir a las "leyes de vagos" u otras legislaciones locales que imponen el servicio a las armas a modo de castigo para ciertos delitos, y con ellas habilitan la inclusión de extranjeros en el contingente ${ }^{26}$. A veces el uso de la palabra "contingente" era intencionado, si lo utilizaban los jefes de las fuerzas nacionales para convocar a la población eran llamados guardias nacionales,

25 Numerosos testimonios aparecen refrendados en nuestra tesis doctoral.. Lucas Codesido, Armar al Estado, construir la Nación. La nacionalización de las fuerzas armadas en la Argentina y su vinculación con el proceso de construcción del Estado nacional" (Tesis de Doctor en Historia. La Plata. Fahce/UNLP, 2016).

26 En primer lugar, se menciona para el contingente a los individuos que no se hallan enrolado en la Guardia Nacional o que hayan desertado de su servicio y luego aparecen las otras opciones. Así lo establece un decreto del 28 de enero de 1870 y la Ley de Reclutamiento de 1872 Ercilio Domínguez, Colección de Leyes y Decretos, 353-354 y 421-423. 
si lo utilizaba el general Peñaloza esos contingentes eran calificados de montoneros ${ }^{27}$.

\section{Destinados a servir: composición social y EVOlución de UNA FUERZA DE LÍNEA (1867-1882)}

Antes de comenzar con el análisis de las relaciones jerárquicas dentro de la fuerza de línea queremos mostrar un breve análisis acerca de la conformación y evolución de una fuerza de línea durante un lapso aproximado de quince años. Nos interesa entrever, a partir de algunos datos concretos, qué tipo de correlato efectivo había entre las representaciones sociales que refieren a los cuerpos de línea como órganos de punición y la materialidad de los números concretos asentados en algunos libros militares que aún se conservan. Para ello hemos podido examinar el registro de altas y bajas del Regimiento $11^{\circ}$ de Caballería de Línea, donde aparece apuntado el origen y destino de los individuos de tropa que pasaron por esa unidad entre 1867 y $1882^{28}$ (Cuadro 1).

Cuadro 1. Altas del Regimiento $11^{\circ}$ de Caballería de Línea, 1867-1882

\begin{tabular}{|c|c|c|c|c|c|c|c|}
\hline Enganchado & Voluntario & Personero & Destinado & Recargado & Reenganchado & Distinguido & $\begin{array}{c}\text { Desertor } \\
\text { aprehend. }\end{array}$ \\
\hline 205 & 52 & 5 & 432 & 5 & 24 & 8 & 10 \\
\hline
\end{tabular}

Fuente: EMGE, Servicio Histórico, Registro de Altas y Bajas, Regimiento $11^{\circ}$

Caballería de Línea, 1867-1882.

Los datos nos muestran que durante esos quince años se registraron un total de 753 altas, dadas según las diversas figuras legales por las cuales se ingresaba al servicio. Las denominaciones que aparecen allí son ocho: Enganchado, voluntario, personero, destinado, recargado, reenganchado,

$27 \mathrm{Al}$ estallar la guerra contra el Paraguay el gobernador Campos aconsejaba evitar el uso del término contingente al ministro de guerra. Consciente del rechazo con que los habitantes de La Rioja percibían aquella palabra asociada con el reclutamiento forzoso "Cuando precisen fuerzas o milicias de las Provincias, no pidan contingentes, porque la sola palabra basta para introducir la alarma y despoblar pueblos enteros. Pidan por Batallones o por Compañías, pero no se sirvan de la palabra `contingente" ' Isidro Ruíz Moreno, Campañas militares argentinas. La política y la guerra. Guerra exterior y luchas internas (1865-1874) (Buenos Aires: Claridad, tomo 4, 2008), 56.

28 EMGE, Servicio Histórico, Registro de Altas y Bajas, Regimiento $11^{\circ}$ Caballería de Línea, 18671882. 
distinguido y desertor aprehendido. De esas 753 altas hay 12 que no contienen los datos acerca de la forma de ingreso a la unidad, quedando 741 registradas. Sobre esa cantidad 432 responden a la figura del destinado, lo que lleva a concluir que por esta condición ingresó a esta unidad el 58,3 \% del total de la fuerza en esos quince años. Recordemos que se era destinado al servicio de las armas por delitos comunes o políticos, por infractor de la ley de enrolamiento, o simplemente por ser "vago y malentretenido". Hay que tener en cuenta además que el número de altas en este regimiento no se corresponde con igual número de individuos pues muchos de los destinados o voluntarios que cumplían el servicio aparecen como enganchados luego, o reenganchados si ya tenían contrato de enganche. De este modo algunos individuos dados de alta como destinados aparecen algunos años después -luego de cumplir su condena- entre los nuevos enganchados. Contabilizados en ambas figuras dentro del total, el número de individuos cuyo ingreso al servicio se impuso como condena oscila en torno al $61 \%$ del total ${ }^{29}$. A ellos se agrega la figura del personero que, si bien es alguien que suplanta a otro a cambio de una compensación monetaria, en la mayoría de los casos aparece en substitución de un destinado al servicio militar. Con lo cual la cantidad de personal de tropa asociado a la figura punitiva se eleva aún más. Los recargados con más años de servicio por faltas cometidas durante su desempeño en la fuerza se suman al refuerzo de esta figura.

Llegados a este punto podemos hacer otra observación que tiene que ver con las diferencias sociales entre la tropa y la oficialidad: es ilustrativo por el hecho de que el recurso al recargo del servicio sea aplicado al soldado de tropa como sanción, mientras que las faltas cometidas por oficiales conducen a lo contrario, es decir, podían dar lugar a la baja del empleo. Evidencia

29 Hay 36 destinados que luego hicieron contrato de enganche, dos de ellos aparecen como personeros en sustitución de dos infractores de la ley de enrolamiento para la Guardia Nacional. Los 5 recargados son desertores aprehendidos que se sumarían a los otros 10 que aparecen bajo esta figura. Hay otros 48 nombres dados de baja por desertados sin más información. El porcentaje de deserción según los datos que aparecen en el registro es de $8,2 \%$ (64 casos). Aunque presumimos que el número es considerablemente mayor debido a que hay varios nombres de soldados inscriptos sin más datos que probablemente no llegaron a ser dados de alta estando vacío el casillero de "Toma de Razón" donde figura esa fecha y como no han ingresado oficialmente al servicio se consideran entre los desertores. 
de la distancia existente entre los componentes de la tropa y los oficiales.

\section{SUBORDINACIÓN Y DISCIPLINA: ENTRE EL TEMOR Y LA QUERENCIA}

Según contaba el comandante Prado al recordar su vida como recluta en la frontera había dos tipos de soldado cumpliendo aquel servicio. Los primeros eran los que "se aquerenciaban y vivían contentos y felices, conceptuando que para ellos el mundo era el cuartel, y la familia el escuadrón”. Mientras que los segundos:

"más indomables o menos filósofos, tomaban la cuestión por el lado trágico, y en la primera oportunidad desertaban. De estos, muchos conseguían escapar y libertarse. Los demás eran aprehendidos; y entonces les esperaban las estacas y el recargo ilimitado, o como al desgraciado Verón, la muerte" ${ }^{30}$.

Resignarse y aceptar que "el mundo era el cuartel y la familia el escuadrón” o escapar de la desventura desertando eran las opciones que evoca en su relato el antiguo soldado Manuel Prado al referir aquellos días en la frontera a fines de la década de 1870. La primera alternativa parecía ser más sencilla pues solo se trataba de encontrar el momento adecuado para escapar, aunque sus consecuencias podían ser terribles si se era aprehendido. La segunda requería una predisposición especial, vinculada a una suerte de resignación que Manuel Prado asocia con la sabiduría. Era cosa de "filósofos".

En marzo de 1870 Julio Roca, al frente de una fuerza de línea estacionada en Tucumán, le escribía al ministro Gainza aconsejándole medidas para formar cuerpos de línea disciplinados donde la deserción pudiera dejar de ser un gran problema y lograra convertirse en un fenómeno aislado. El gran "secreto" para lograr esos objetivos según el entonces teniente coronel Roca es que "no se puede tener ni formar cuerpos de línea si no se les paga cada 30 de més" y a ello agrega que su batallón "vive en un cuartel estrecho e incómodo y está completamente descalzo", el calzado

30 Manuel Prado, Guerra al malón (Buenos Aires: Editorial Americana, 1942), 106. 
que había recibido hacía ya tres meses "no le duró ni mes por su pésima calidad”. Luego agregaba el oficial Roca:

"Si V. E. me hubiera atendido como es debido le hubiera formado un cuerpo que nada hubiera dejado que desiar. Si me hubiera dado dinero para seguir el enganche, que hace tres meses lo menos lo hemos suspendido hubiera remontado mi batallón a 400 plazas, y le tendría completado este número, un depósito de reclutas que se irían remitiendo, custodiados por soldados del $7^{\circ}$ a donde V.E. los destinase. El gaucho tucumano es el más civilizado de la República y por consiguiente está acostumbrado y aspira a mejores comodidades. Es necesario, pués, atenderlo sinó mejor, al menos igual a los demás soldados del ejército. Sé que las fuerzas de Salta están talvéz en peores condiciones que éstas, y que la deserción pronto las reducirá a cero.... Pedí permiso para hacer propuestas, no lo concedieron: las elevé, y a pesar de hacer muchísimo tiempo, hasta ahora creo que ni piensan despacharlas. Así pocos oficiales habrá tan abnegados que puedan servir con gusto" 31 .

Roca había llegado a Tucumán el año anterior para intentar poner en "condiciones" al $7^{\circ}$ de línea que fue trasladado a esa provincia. Preocupándose por aumentar el número de plazas, se propuso recurrir al reclutamiento de la población rural local. En principio solo quería prestar atención a la instrucción de sus hombres, para los que había hecho imprimir un pequeño manual que él mismo redactó -adaptación del Manual de Perea ${ }^{32}$ y que es el único texto sobre materia militar que se le conoce $-{ }^{33}$. Pero los factores sociales descriptos en sus reportes hacían que sus preocupaciones se di-

31 Julio Roca a Martín de Gainza, Tucumán, 21 de marzo de 1870. AGN, Fondo del Museo Histórico Nacional, Legajo 36, documento 4461.

32 El Manual de Cabos, Sargentos, oficiales y jefes dispuesto para el Régimen, Disciplina y Subordinación del Ejército es una obra española de 1856 y en 1857 por Orden Real fue declarada texto oficial para la instrucción de los cuerpos de infantería y artillería de la Marina Española. En 1874 la obra de Perea circula en el Ejército Argentino en su quinta edición, aumentada con el "Manejo del Arma" de Luis María Campos. Joaquín Rodríguez Perea, Instrucción General Militar (Buenos Aires: Editor Ángel Medina, 1874 [1856 edición original]).

33 Julio Roca, Manejo del Arma de Infantería. De las V y VI ediciones de la Obra de Perea, arreglada para el Batallón $7^{\circ}$ de línea por su jefe el teniente coronel Don Julio Roca (Tucumán: Imprenta de la Victoria, 1869). 
rigieran a solicitar el remedio indispensable para poder generar las condiciones en las que pudiera desarrollar mínima y efectivamente un entrenamiento militar. En ese marco presenta Roca aquel retrato casi sociológico acerca de las características sociales propias del "gaucho tucumano" y el modo con el que debe ser tratado y atendido para conseguir hacer de este un buen soldado.

Varias claves para analizar la naturaleza organizativa de esos cuerpos de línea, dejan los reportes de Roca y de otros jefes militares. En primer lugar, dentro de las recomendaciones y regaños que hace al ministro acerca de la situación de la tropa que manda, aparecen cuestiones básicas que hacen a la subsistencia humana. Estas van desde calzado, vestimenta, pago de haberes, hasta las partidas para mejorar las instalaciones del cuartel. Es central el tema de la alimentación y el abastecimiento de las tropas, que cuando escaseaba era la causa de los mayores desbandes. Así lo atestigua Fotheringham en sus memorias cuando recordaba una jornada previa a la batalla de Santa Rosa en que "todo el día se marchó sin probar bocado. Yo creo que desertaron más de doscientos y aún me quedo corto"34. Los aspectos básicos se configuraban como el primer gran obstáculo que debía sortear el jefe militar para luego poder trabajar sobre la cuestión técnica de la instrucción del arma y la disciplina que produciría la transformación de esos gauchos en soldados. Sobre la alimentación, recuerda Manuel Prado que tuvo que esperar a un nueve de julio, fecha patria, para que "por vez primera, después de un año, se mataron reses vacunas" pues en general "en el campamento, la tropa comía yeguas y en los fortines los pocos avestruces que podían bolear los milicos en los mancarrones flacos y extenuados" ${ }^{\prime 3}$, ello con el permiso de los jefes o mandados por estos.

Otra cuestión que surge de los partes militares es que dentro del papel desempeñado por los jefes militares aparece la condición de saber detectar las habilidades de sus oficiales subalternos y de los soldados que demuestran aptitudes para la conducción. El reconocimiento y la premiación de los ta-

34 Ignacio Fotheringham, La vida de un soldado (Buenos Aires: Ciudad Argentina, 1999), 319 [1909 edición original].

35 Manuel Prado, Guerra al malón, 55-73. 
lentos individuales que realiza el jefe se traducían en las "propuestas" a las que se refiere Roca, que son los pedidos que elevó al Ministerio de guerra para los despachos de ascenso a oficiales que reclama. Este reconocimiento dado por el jefe de la unidad es muy importante como incentivo para reforzar la lealtad y conseguir un mayor compromiso de sus subalternos con una función específica.

\section{Soldados VIEJOS, SOldAdOS NUEVOS}

"Después de considerársele durante largo tiempo un soldado sospechoso, vigilado como un animal salvaje, se había convertido en un viejo soldado, un perro fiel..."36.

Así se refería el ingeniero Ebelot a un sargento del regimiento $11^{\circ}$ de caballería en la guarnición Puán. Un soldado de origen "cristiano" que había sido rescatado de las filas indígenas donde había pasado largos años viviendo, habiéndose adaptado y asimilado a la vida de las tolderías. Un rescate no deseado por la víctima cuando una fuerza de línea atacó una toldería y lo incorporó por la fuerza en sus filas. El regreso desde el más allá -de la frontera- se produjo "muy a pesar suyo, aunque sin hacerse demasiada violencia y aceptando con filosófica resignación” este nuevo destino como soldado del ejército. Desde aquel momento -continúa relatando Ebelot- habían transcurrido ocho años en los que podrían integrarse completamente, siendo asimilado a la unidad de línea "sin que nadie tuviera una queja de él”37. Ya podía ser considerado un soldado viejo.

Los viejos soldados o veteranos son aquellos oficiales subalternos y soldados ya instruidos militarmente y familiarizados con las diversas circunstancias que atravesaba la unidad. Han aprendido a obedecer de acuerdo con la impronta del tipo de mando que ejerce el jefe de la unidad. Una de las funciones más destacadas que ejecutarán estos soldados de confianza será la misión de "custodiar" - literalmente- la incorporación y los desplazamientos de los nuevos reclutas agregados a la unidad para evitar su deserción. Por este motivo el soldado "veterano" siempre será el que tenga

36 Alfredo Ebelot, Recuerdos y relatos de la guerra, 161.

37 Alfredo Ebelot, Recuerdos y relatos de la guerra, 160. 
preeminencia dentro de la tropa. El veterano ya ha acompañado al jefe en distintas situaciones en las que ha probado su lealtad y subordinación.

A la hora de remontar y organizar una fuerza de línea, frecuentemente los jefes calculaban las posibilidades de éxito o fracaso - para lograr disciplinar y "moralizar" a los efectivos de su cuerpo- haciendo una estimación de la proporción entre cantidad de soldados veteranos y de nuevos reclutas, entre ellos los "presos soldados" destinados por delitos y los "gringos personeros" recién traídos o con poco tiempo de ser incorporados y adoctrinados. Si estimaban que había pocos veteranos y muchos reclutas la situación podía constituir un serio problema para esos jefes militares. Así lo expone Joaquín Viejobueno en un parte al ministro Gainza desde Córdoba en 1870 al enumerar las causas de un motín sucedido en las fuerzas de su mando. Relata que "el número de los presos soldados y paisanos nuevos no baja de cincuenta”, estos habían sido recibidos para remontar las plazas de su fuerza, "es indudable que el limitado número de tropa vieja los ha impulsado [a los nuevos] a llevar adelante su pensamiento". Agrega además que la mayoría de los soldados veteranos que necesita para vigilar a los nuevos ya están cumplidos de su servicio y por ello solicita al ministro autorización y fondos para reengancharlos allí mismo, puesto que si les concediera la baja "es casi imposible que una vez en Buenos Aires se reenganchen", y necesita ahora no solo para la instrucción sino también para la custodia de los sublevados "soldados de confianza y ninguno pueden inspirármela mejor que aquellos á quienes he educado y que por mucho que se hallan desmoralizado, creo que algún respeto y cariño me tendrán" 38 .

Por la misma época el ministro Gainza le pregunta a Julián Murga, entonces estacionado en Patagones, si cuenta con muchos soldados de confianza en su tropa, a lo que Murga responde: "no me atrevo a asegurarle que sí, porque los que tengo, todos son presidiarios de la cárcel; yo para mí la tengo, la escolta que llevé a Pillahuincó era de ellos y en el encuentro con los indios no me han dejado que desear" 39 . Histórico Nacional, Legajo 36, documento 4462.

39 Julián Murga a Gainza, Patagones, 18 de marzo de 1870, AGN, Fondo del Museo Histórico Nacional, Legajo 36, documento 4457. 
Sin personal veterano al cual confiar el cuidado del resto de la tropa se ponía en peligro no solo la disciplina de la unidad sino también la propia vida del oficial al mando. El temor a su propia tropa era un sentimiento bastante frecuente en los oficiales al mando, decía Eduardo Gutiérrez que "como los cuerpos de línea son remontados con pampas y vagos, cuando no con criminales, el oficial no tiene confianza en sus cuatro o seis soldados, porque teme que lo asesinen para desertar, y no se atreve a dormir sino a intervalos irregulares y llenos de sobresaltos" ${ }^{20}$. En el mismo sentido puede leerse el libro de Órdenes Generales del Regimiento $2^{\circ}$ de caballería de linea estacionado en el fuerte Lavalle en agosto de 1874:

"-Servicio para mañana-

Guardia de la Comandancia en Jefe: el sargento $2^{\circ}$ Secundino Salas, Cabo $1^{\circ}$ José Roldán y $2^{\circ}$ Rosario Arias, y ocho soldados viejos.

Guardia de Prevención: el sargento $2^{\circ}$ Juan Rivero, cabo $1^{\circ} \mathrm{Da}-$ maso Ramos, id $2^{\circ}$ Ramón Ríos, trompa Martín chico, y diez y seis soldados viejos para entrar de noche y veinte soldados nuevos durante el día, retirándose diez y seis de ellos á la noche, quedándose solamente cuatro" ${ }^{\prime 1}$.

Órdenes similares se repiten en el transcurso de los días y durante varias semanas en aquel expediente donde se describen las actividades diarias. Hemos constatado que el comando en jefe de la fuerza es custodiado solamente por "soldados viejos", aquellos cuya lealtad ha sido reconocida. Durante el día se confía la participación de algunos nuevos junto con los veteranos. En tanto que la oscuridad de la noche, al ser más propicia para facilitar posibles deserciones y motines, obligaba a que la tropa nueva sea reemplazada casi por completo por los "soldados viejos" en las rondas nocturnas. Las consecuencias de no ejecutar estas precauciones colocando soldados de confianza en una guardia nocturna podían ser fatales. En febrero de 1881 se produjo la muerte de diez soldados, un jefe, y dos oficia-

$40 \quad$ Eduardo Gutiérrez, Croquis y siluetas militares (Buenos Aires: Eudeba, 1960), 157-158.

41 EMGE, Servicio Histórico, Libro de Órdenes Generales, Regimiento $2^{\circ}$ de Caballería de Línea, años 1874-1877, Orden del 16 de agosto de 1874, p. 13. 
les luego de una sublevación de reclutas recién incorporados al regimiento $11^{\circ}$ de Caballería de Línea que marchaban hacia la línea de Neuquén. De aquel trágico desenlace daba cuenta Rufino Ortega -jefe del Fuerte General San Martín- al Inspector de Armas de la Nación. Reportó que el 27 de enero envió desde ese fuerte a la línea del Neuquén dos compañías del batallón $12^{\circ}$ de infantería con 45 destinados del $11^{\circ}$ de caballería a las órdenes del Ayudante Mayor Trifón Cárdenas, al que le encargó estas precisas instrucciones sobre el trato que debía dar a los nuevos reclutas:

Al dar mis últimas disposiciones á dicho oficial le previne con insistencia que á cuarenta y tantos reclutas correntinos que pertenecían á las compañías del batallón no solamente no les utilizace en el servicio sino que debía tomar todas las medidas que le respondiesen a la seguridad de ellos. Desde el río Diamante el ayudante Cárdenas contraviniendo mis órdenes hizo alternar en la guardia á los reclutas con los soldados de confianza. En la noche del día 11 campadas las fuerzas en Río Grande los correntinos que en su mayor parte componían la guardia de seguridad á la voz de "indios" unidos con los cuarenta y cinco destinados del Regimiento 11 se lanzaron sobre los pabellones y mientras los unos hacen fuego sobre los oficiales y soldados de confianza los otros arrojan el armamento que no pueden utilizar al río. Habiendo quedado en el primer momento el ayudante Cárdenas muerto $\mathrm{y}$ dos oficiales gravemente heridos se hace imposible por esto $\mathrm{y}$ por la falta de armas tomar medidas que conduzcan á contener la sublevación. Los sublevados después de dejar diez soldados muertos y doce gravemente heridos se apoderan de la mulada emprendiendo en número de ochenta la fuga hacia Chile" ${ }^{\prime 2}$.

Hay que señalar que la mayoría de las deserciones no se dieron en cualquier ocasión, acontecían en los momentos en que las fuerzas se movilizaban. Los reclutas sublevados generalmente pertenecían a contingentes

42 Reporte de Rufino Ortega al Inspector y Comandante General de Armas de la Nación, 14 de febrero de 1881. En Memoria del Ministerio de Guerra, Anexo A, Tomo II, Buenos Aires, s/e, 1881, pp.552553. 
provinciales recientemente incorporados. Estos dos rasgos permiten suponer que, entre los factores que favorecían la deserción, aparecían con frecuencia ciertos vínculos previos de origen entre los amotinados, que les permiten rebelarse contra el dispositivo disciplinador impuesto por los jefes $^{43}$.

\section{Mujeres y Familia}

Una mención que nos interesa dejar consignada y que hemos desarrollado en otro trabajo ${ }^{44}$ es el papel desempeñado por las mujeres en las milicias y el ejército. Este ha sido poco estudiado y merecería una mayor atención debido a la gran cantidad de referencias en las fuentes de la época. Hay pocos estudios que han abordado la temática ${ }^{45}$ pero en los relatos y testimonios de quienes sobrellevaron esa vida azarosa son frecuentemente mencionadas ${ }^{46}$. En general, el rol de la mujer aparece de modo frecuente en la memoria de los mecanismos "anti-deserción", pues su presencia en los campamentos y fortines ayuda a sujetar los lazos que unen al soldado con su unidad. Las evocaciones sobre las mujeres en la vida militar en su mayoría responden a una visión que construye lo femenino por fuera de la institución militar, desde miradas que suponen al ejército como una institución esencialmente masculina. La mujer aparece como un actor secundario en un guion escrito por hombres y para ser protagonizado por ellos mismos. La figura femenina resultante de esa construcción cultural ${ }^{47}$ se asocia en general con los efectos negativos o positivos de su presencia en el espíritu de la tropa. Para Manuel Prado ellas eran "la alegría del campamento y el señuelo que contenía en gran parte las deserciones. Sin esas mujeres, la existencia hubiera sido imposible. Acaso las pobres impedían

43 Alejandro Rabinovich realiza una observación similar sobre las modalidades que adquiere el problema de la deserción en el período independentista (2011).

44 Lucas Codesido, Armar al Estado, construir la Nación. La nacionalización de las..., 2016.

45 Alejandro Rabinovich, Ser soldado en las guerras de independencia. La experiencia, 2013.

46 Relatos de viaje y testimonios de Alfredo Ebelot, Manuel Prado, Álvaro Barros, Ignacio Fotherimgham, José Daza, Prudencio Arnold, Eduardo Racedo, entre otros.

47 Aquí retomamos las reflexiones de Peter Burke acerca de la construcción de la clase y el género, entendidas como papeles sociales o representaciones de un guion que se construye culturalmente, antes que realidades concretas o materiales. Peter Burke, ¿Qué es la historia cultural? (Barcelona: Paidós, 2006), 104-105. 
el desbande de los cuerpos”48. El ingeniero francés Alfredo Ebelot aseguraba haber sido testigo de cómo "los cuerpos de línea reclutan en sus peregrinaciones a través de las provincias, y llevan consigo continuamente a remolque, casi tantas mujeres como cuentan de soldados. El Estado tolera y hasta favorece esta costumbre". Por este motivo "un jefe cuidadoso -dice Ebelot- se alarma cuando ve disminuir el personal femenino de su tropa: esta puede desmoralizarse" 4 .

Además de la valoración positiva acerca de la presencia femenina y las familias dentro de los regimientos, hay frecuentes observaciones acerca de las mujeres de "mal vivir" en las fuerzas de Línea. El fenómeno de la promiscuidad sexual como una práctica que no puede erradicarse y sobre la que se debe tomar correctas medidas de higiene aparece mencionado por los médicos del ejército, quienes conviven diariamente con las afecciones de los soldados. Este problema fue uno de los causantes de las mayores bajas de soldados en las unidades de línea durante el período de la llamada "Campaña al Desierto". Las memorias del Ministerio de Guerra de los años 1878 a 1881 dan cuenta del fenómeno de la sífilis y el alto número de infectados en las filas ejército. Los informes médicos incluidos en las memorias de Guerra contienen sentencias muy claras sobre el peligro que la política militar debe afrontar: "La frecuencia de esta enfermedad proviene á no dudarlo del número de mujeres de mal vivir que por desgracia hay en todos nuestros cuerpos de ejército, y del total abandono que reina en la higiene á ese respecto" ${ }^{50}$. Los médicos del Hospital Militar, encargados de redactar los informes al ministerio asocian de manera proporcional al número de soldados infectados con la cantidad de mujeres que conviven junto a ellos portando la enfermedad ${ }^{51}$. Al ser padecimientos que además

48 Manuel Prado, Guerra al malón, 74.

49 Agrega Ebelot que "Un regimiento sin mujeres perece de aburrimiento y suciedad y ve aumentar notablemente el número de las deserciones (...) A ellas se destina el único pedazo de pan, la última pipa de tabaco, el mejor caballo". Alfredo Ebelot, Recuerdos y relatos de la guerra, 184-185.

50 Memoria del Hospital Militar, 28 de marzo de 1879. En Memoria del Departamento de Guerra y Marina, Imprenta de El Porteño, 1879, p.163.

20251 Los datos del hospital militar para todo el año 1878 muestran que ingresaron al mismo durante todo el año 499 militares, de ellos, las afecciones más frecuentes son la bronquitis, sífilis, tuberculosis y venéreos, y "respecto al venéreo y la sífilis, cuya cifra de 33 sifilíticos y 121 venéreos hacen un total de 154 de enfermedades adquiridas fuera del servicio". Memoria del Hospital Militar, En Memoria 
de la salud afectaban al prestigio de quien la contraía, hubo numerosos casos de oficiales que intentaban ocultar los síntomas de la enfermedad venérea hasta que estos se hacían demasiado evidentes ${ }^{52}$.

\section{LAS VIRTUDES DEL “BUEN” JEFE}

Una vez atendidas las necesidades básicas y siendo superado el tiempo dentro del cual el jefe de un cuerpo lograba desarrollar la instrucción militar, el fantasma de la deserción parecía comenzar a esfumarse. En el transcurso de esa convivencia se ponían en juego algunos elementos que nos ayudan a comprender el carácter de la relación que se construye. Precisar el tipo de liderazgo compuesto en esa convivencia entre quienes mandan y obedecen es lo que refería Mansilla en su alegato donde niega los fusilamientos. El "cariño" y la consideración de sus subalternos antes que los grillos y las "carreras de baqueta" son las claves que quiere transmitir a la hora de explicar su accionar. Masilla entendía que antes de aplicar el terror del castigo "ejemplar" prefería como método disuasivo un tipo de autoridad más indulgente que motivaba la subordinación de sus soldados a partir de la visión que estos tenían acerca de un jefe preocupado por las penurias y necesidades de su tropa. Así, coloca en primer término las aptitudes del jefe para conducir, ganarse el respeto de la tropa y forjar en ella el sentimiento de subordinación necesario para la sujeción de sus miembros al cuerpo militar, cuestión que permitiría ejercer la autoridad de forma efectiva. El carisma y el liderazgo entonces no aparecen vinculados a la imposición de un modelo impersonal y burocrático sino a una negociación propia de relaciones personales en donde las representaciones de los subalternos juegan un importante papel ${ }^{53}$.

Otro aspecto que surge del rol desempeñado por los jefes es que, en su del Departamento de Guerra y Marina, Imprenta de El Porteño, 1879.

52 Entre ellos, un oficial del $3^{\circ}$ de Infantería Juan Isidro Díaz "que por un digno pundonor militar, no quiso darse con parte de enfermo y confesar una blenorragia de que padecía, sufrió un absceso del tamaño de una naranja". Doctor Pedro Dupont a Eduardo Racedo. Eduardo Racedo, La conquista del Desierto, Memoria militar y descriptiva de la $3^{\circ}$ División expedicionaria (Buenos Aires: Editorial Plus Ultra, 1965), 230.

53 Peter Burke, Historia y teoría social (Buenos Aires: Amorrortu ediciones, 2007), 113. 
figura se personifican las virtudes de los cuerpos que dirigen. Esta idea debía arraigarse en la visión de la tropa, pues el valor del jefe representaba el valor de la unidad. En su desempeño militar el jefe debía encarnar, para lograr luego transmitir, los valores que la tropa debía asimilar. De esta manera se hacía presente el llamado espíritu de cuerpo, ese punto en que "los cuerpos se funden como la nieve al cabo de un tiempo que varía según las circunstancias, sobre todo según el jefe que los dirige" 54 . Por ello, un jefe con mando efectivo de su unidad era aquel que desde el punto de vista de los subordinados ha conquistado los méritos suficientes para conducirlos. A ello se refiere Manuel Prado al relatar su propia experiencia como soldado y las relaciones con sus jefes:

"sin el convencimiento individual arraigado en el espíritu del soldado de que su jefe u oficial vale más que él, como guapo, como gaucho y como audaz en el peligro, no hubiera habido guerra posible con el indio... Del valor del jefe dedúzcase la conducta del soldado" 55 .

Si la deserción aparecía como el ejemplo "desmoralizador" de toda disciplina y sujeción en la tropa, la demostración de las aptitudes guerreras de los jefes en la percepción de los soldados aparecía como uno de los actos "moralizadores" más significativos para conseguir la obediencia. Eduardo Gutiérrez, que fue oficial -capitán- de frontera a comienzos de la década de 1870, refiere en su "Croquis y siluetas militares" algunos ejemplos de lo que significaba el peso de la figura de un jefe valeroso desde la perspectiva de su tropa ${ }^{56}$. Un episodio se dio durante la rebelión mitrista cuando el coronel Francisco Borges había entregado el batallón de su mando -el $2^{\circ}$ de infantería- que respondía al gobierno para ir a unirse a las fuerzas

54 Alfredo Ebelot, Recuerdos y relatos de la guerra, 119.

55 Manuel Prado, La conquista de La Pampa, Cuadros de la guerra de frontera (Buenos Aires: Librería Hachette, 1960), 69-70 [1892 edición original].

56 Hay que aclarar que, si bien el autor del Juan Moreira era un escritor de folletines literarios, los "Croquis y siluetas militares" ocupan un lugar singular dentro de su producción literaria. Allí relata su experiencia personal y, aunque sus recreaciones contienen componentes ficcionales concebidos para producir algún tipo de impacto en los lectores de su tiempo, los personajes que aparecen fueron conocidos por él, tanto los jefes -Hilario Lagos, Luis María Campos o Francisco Borges- como los soldados que tenía bajo sus órdenes. 
rebeldes del mitrismo. Cuenta Gutiérrez que luego de ser él mismo designado jefe al mando de esa unidad, quiso evitar por todos los medios que la tropa supiese que Borges ahora estaba con los mitristas, puesto que "si el batallón lo ve o sabe que está allí, no solo no obedecerá mi voz, sino que sin la menor vacilación tratará de incorporársele; conozco los oficiales y los soldados" 57 .

El avance de la línea de frontera durante 1877 sería un acontecimiento propicio para que los jefes que actuaban en la línea que avanzaba sobre el "desierto" demostraran algunas de esas conductas que giraban en torno del culto al valor. Unos cuantos jefes de esas unidades habrían de morir debido a sus constantes tentativas por entreverarse con alguna fuerza indígena o internarse en sus dominios en inferioridad de condiciones. Esos hechos produjeron la alarma del ministro Alsina quien luego de la muerte del Teniente Coronel Undabarrena -comandante de un fortín de la línea de Italó- dio a conocer una orden general para todos los oficiales con mando en sus unidades en la que les ordenaba no arriesgar inútilmente sus vidas. Para lograr convencerlos de desistir de esa actitud Alsina distinguió lo que consideraba actos de "valentía" -que valoraba positivamente- de otra actitud que definía como "arrojo temerario" y que producía bajas inútiles. Buscando evitar esta última conducta expresaba:

"Los jefes del Ejército Argentino tienen adquirida ya, como bravos, una reputación inconmovible, y, para conservarla no deben jugar imprudentemente con la vida. (...) Por actos de arrojo iguales o parecidos a los que motivan esta nota perecieron Heredia, Ortega y Jáuregui, jefes que eran una esperanza para el Ejército Argentino, y en prevención de estos recuerdos dolorosos, es un deber a la vez que un derecho propender a que no se repitan sucesos de carácter tan lamentable" 58 .

Luego recordaba el ministro que -en caso de sobrevivir a ellos- esos actos eran sancionables pues iban en contra de las Ordenanzas Militares que "califican como delito punible ante los consejos de guerra, el abandono

58 Manuel Prado, La conquista de La Pampa, Cuadros de la guerra, 54. 
que un oficial hace de su puesto en cualquier acción de guerra o marchando a ella". Luego dejaba en claro que "las consideraciones que dejó expuestas jamás podrán ser miradas como una reprobación para los bravos o como un aliento para los cobardes" 59 .

\section{BALANCES: EJÉRCITO VIEJO Y EJÉRCITO NUEVO}

Hemos examinado algunos elementos que nos ayudan a comprender el carácter de la relación que se construye en el transcurso de la convivencia entre oficiales y soldados. Vinculamos la construcción del liderazgo por parte del jefe militar, a partir de la mirada del soldado que debe subordinarse y obedecer, cuestión que permitiría sostener la autoridad de forma efectiva. El carisma y el liderazgo no aparecen vinculados a la imposición de un modelo impersonal y burocrático sino más bien como el fruto de una negociación propia de relaciones personales, en donde las representaciones de los subalternos juegan un importante papel. Un tipo de autoridad que motivaba la subordinación de sus soldados a partir de la visión que estos tenían acerca de un jefe preocupado por las penurias y necesidades de su tropa. Además, la posibilidad de elevar las "propuestas" al Ministerio de Guerra, que son los despachos de ascenso a oficiales, constituía un importante incentivo para reforzar la lealtad y conseguir un mayor compromiso de sus subalternos con una función específica. Luego indagamos acerca de la diferencia entre los soldados viejos y soldados nuevos, en relación con las posibilidades de éxito en la construcción de las relaciones de autoridad hacia el interior de la unidad. También pudimos observar que en la demostración de las aptitudes guerreras de los jefes se simbolizaban las virtudes de los cuerpos que dirigen, y en la percepción de los soldados aquello aparecía como uno de los actos más significativos para obtener la subordinación y el llamado espíritu de cuerpo.

Por último, nos resta señalar que las vivencias de escasez, miseria y arbitrariedad en la organización militar, será una cuestión que a los oficiales formados en la academia en años posteriores les resultaba difícil de asimilar como natural e inherente a la vida militar. Con la llegada del roquismo

\footnotetext{
59 Manuel Prado, La conquista de La Pampa, Cuadros de la guerra, 55.
} 
al gobierno empieza a notarse la diferencia entre los oficiales formados en la dura disciplina de los cuerpos y los que se educaron en la academia militar. José Daza a poco de incorporarse al ejército fue testigo de una escena donde se aplicó la famosa "carrera de baqueta" a seis desertores del regimiento de caballería en junio de $1874^{60}$. La impresión de esos hechos en su sensibilidad se intensificaba, según el relato que hace Daza, debido a la impronta de la formación militar recibida:

“...ingrato efecto me causó; tanto más, habiendo sido alférez recién egresado del Colegio Militar, donde se nos había enseñado el derecho de gentes, ó de humanidades, tendiente á mitigar los horrores de las guerras. Allí no existía ningún enemigo, no se libraba ningún combate; sin embargo, veía correr raudales de sangre y cometer actos reñidos con la cultura nacional"61.

Con la llegada de Roca al ministerio de guerra y luego a la presidencia, el problema social que contenía para la sociedad de su tiempo la composición, modos de reclutamiento y la propia existencia del Ejército permanente se diluye con la asociación que el discurso roquista realiza entre el Ejército y el Estado. La revalorización del papel del Ejército en la empresa de avance estatal sobre las sociedades indígenas conduce a vincular el problema de los soldados a partir de 1878 con una cuestión de administración ineficiente de los recursos. En esa perspectiva, la arbitrariedad de las prácticas militares es "solucionada" con el licenciamiento o la promesa de este para todos los civiles movilizados en las fuerzas nacionales. El discurso roquista asegura reconocer las injusticias pasadas dentro del Ejército de Línea. Aquellos soldados que han cumplido su servicio y en su mayoría no es posible licenciar, son reconocidos como tales y se proponen soluciones que llegarían en un futuro próximo. Los vicios y deficiencias de la administración militar prometen ser corregidos cuando puedan ponerse en

60 Los reos debían atravesar entre dos filas de soldados armados con plantas de varilla. Mientras algunos condenados elegían pasar corriendo entre las filas, otros "caminaban al paso, cual mártir del Gólgota. Tanto los que corrían como los que no, recibieron trescientos varillazos, desgarrándoles los pulmones, salpicando una lluvia de sangre". José Daza, Episodios Militares (Buenos Aires: Librería La Facultad, 1914), 83.

61 José Daza, Episodios Militares (Buenos Aires: Librería La Facultad, 1914), 84. 
práctica las reformas que Roca planea realizar una vez finalizado el avance de la frontera y que por el momento solo deja brevemente consignadas en la presentación de su memoria de 1878 (Ministerio de Guerra y Marina, 1878).

Al comenzar la década de 1880 ya hace varios años que el Colegio Militar provee a los futuros oficiales del ejército. A partir de entonces los oficiales serán los “científicos” que en la década de 1880 se irán sumando a las diversas unidades del ejército. Con el correr de los años y a medida que el número de jóvenes formados en la academia militar fue creciendo y esos oficiales ascendiendo en la escala castrense fue apareciendo una división entre los componentes del llamado ejército viejo y los del ejército nuevo. Los primeros formados en la dura experiencia de los campamentos de la guerra en el Paraguay o las distintas guerras civiles, y los miembros del ejército nuevo compuesto por los científicos que pasaron por las aulas del Instituto de Palermo ${ }^{62}$.

\section{Bibliografía}

\section{Archivos}

Estado Mayor General del Ejército. Servicio Histórico. "Política interna y causas", Organización Nacional, 1860-1880.

\section{Fuentes primarias}

Barros Álvaro. Fronteras y territorios federales de las pampas del sur, Buenos Aires: Hachette, 1975. El texto original es de 1872.

Castellanos, Francisco. Hijiene del Soldado en Guarnición (Tesis para el Doctorado, Facultad de Ciencias Médicas, Imprenta especial para obras de Pablo Coni, Buenos Aires, 1875).

Daza, José. Episodios Militares. Buenos Aires: Librería La Facultad, Dom 1914.

62 Estas diferencias eran conocidas en el ámbito político de la época y aparecen reflejadas en la iconografía militar a partir del Roquismo. En las imágenes que muestran la apariencia de los oficiales, los hombres del Ejército Viejo usaban la visera de los quepis hacia arriba y los bigotes hacia abajo, y los del Ejército Nuevo, las viseras hacia abajo y los bigotes hacia arriba. 
Domínguez Ercilio. Colección de Leyes y Decretos Militares. Buenos Aires: Compañía Sudamericana de Billetes de Banco, 1898.

Ebelot, Alfredo. Recuerdos y relatos de la guerra de fronteras. Buenos Aires, Plus Ultra, 1968. [1879 edición original].

Fotheringham, Ignacio. La vida de un soldado, Buenos Aires: Ciudad Argentina, 1999. [1909 edición original]

Gutiérrez, Eduardo. Croquis y siluetas militares. Buenos Aires: Eudeba, 1960. [1886 edición original].

Ministerio de Guerra y Marina. Memoria presentada por el Ministro Secretario de Estado en el Departamento de Guerra y Marina al Honorable Congreso Nacional en 1878. Buenos Aires: Imprenta Moreno, 1878.

Ministerio de Guerra y Marina. Memoria del Ministerio de Guerra y Marina. Buenos Aires: Imprenta de El Porteño, 1881.

Prado, Manuel. Guerra al malón. Buenos Aires: Editorial Americana, 1942. [1907 edición original]

Prado, Manuel. Ra La conquista de La Pampa, Cuadros de la guerra de frontera. Buenos Aires: Librería Hachette, 1960. [1892 edición original].

Racedo, Eduardo. La conquista del Desierto, Memoria militar y descriptiva de la $3^{\circ}$ División expedicionaria, Buenos Aires, Editorial Plus Ultra, 1965.

Roca, Julio. Manejo del Arma de Infantería. De las V y VI ediciones de la Obra de Perea, arreglada para el Batallón $7^{\circ}$ de línea por su jefe el teniente coronel Don Julio Roca. Tucumán: Imprenta de la Victoria, 1869.

Rodríguez Perea, Joaquín. Instrucción General Militar. Buenos Aires: Editor Ángel Medina, 1874. [1856 edición original].

\section{Fuentes Secundarias}

Andújar Castillo, Francisco. Ejércitos y Militares en la Europa Moderna. Madrid: Editorial Síntesis, 1999.

Arnold, Prudencio. Un Soldado Argentino. Vida militar del Coronel de la Nación Prudencio Arnold, Rosario: Casa Editora "La Argentina", 1893. 
Bragoni, Beatriz. y Míguez, Eduardo. (Eds.). Un nuevo orden político. Provincias y Estado Nacional, 1852-1880. Buenos Aires: Biblos, 2010.

Burke, Peter. ¿Qué es la historia cultural?, Barcelona, Paidós, 2006.

Burke, Peter. Historia y teoría social. Buenos Aires: Amorrortu ediciones, 2007.

Clausewitz, C. V. De la guerra. Buenos Aires: Círculo Militar, 4 tomos, 1970. [1832 edición original]

Canciani, Leonardo. "Resistencias a la obligación de armarse. Reclutamiento y servicio militar en la Guardia Nacional de frontera", Memoria americana, Cuadernos de Etnografía, Vol. 22 No.1, (2014): 33-63.

Codesido, Lucas. "Las Ordenanzas Militares de Carlos III en la justicia militar argentina: Segunda mitad del siglo XIX", En Revista Contemporânea, Dossié Historia \& Literatura. Núcleo de Estudios Históricos, Universidade Federal Fluminense, Brasil, Ano 3, Vol. 2 No. 4, (2013): 2-23.

Codesido Lucas. "Militarización de la política y política de guerra en el Ejército argentino (1870). Faccionalismo, lealtades políticas y mecanismos de promoción de los jefes y oficiales durante el proceso de construcción del Estado", Historia Caribe, Vol. IX No. 24 (2014): 131-161.

Codesido, Lucas. Armar al Estado, construir la Nación. La nacionalización de las fuerzas armadas en la Argentina y su vinculación con el proceso de construcción del Estado nacional". Tesis de Doctor en Historia. La Plata. Fahce/UNLP, 2016.

Colegio Militar. Reglamento del Colegio Militar Nacional con sus modificaciones. Buenos Aires: Imprenta Especial para Obras de Pablo Coni, 1875.

De la Fuente, Ariel. Los hijos de Facundo. Buenos Aires: Prometeo, 2007. Geertz, Cliffort. Conocimiento local, Ensayo sobre la interpretación de las culturas. Barcelona: Paidós, 1994.

Geertz, Cliffort. La interpretación de las culturas. Barcelona: Gedisa, 2003. Goldman, Noemí. y Salvatore, Ricardo. (Caudillismos rioplatenses. Nuevas miradas a un viejo problema. Buenos Aires: Eudeba, 1998.

Larker, José Miguel. "Las deserciones en la línea de frontera: Formas de resistencia y conflictividad social en la campaña santafesina (18551895)", Ponencia: X Jornadas Interescuelas/Departamentos de Historia, Rosario, 2005. 
Macías, Flavia. y Sabato, Hilda. "La Guardia Nacional: Estado, política y uso de la fuerza en la Argentina de la segunda mitad del siglo XIX", en PolHis, Año 6, No. 11, Primer semestre (2013): 70-81

Macías, Flavia. "El deber de enrolarse y el derecho a votar. Reflexiones en torno a la ciudadanía armada y el sufragio en argentina, 1863-1877", Revista de Indias, Vol. LXXVI, No. 266, (2016): 233-258

Morea, Alejandro. "Las deserciones en el Ejército Auxiliar del Perú durante las Guerras de Independencia en el Río de la Plata, 1810-1820”, Una aproximación cualitativa. Americanía: Revista de Estudios Latinoamericanos, (2015): 159-197.

Míguez, Eduardo. "Guerra y Orden Social en los orígenes de la nación argentina, 1810-1880", anuario IEHS No. 18, Tandil, (2003): 17-38.

Oszlak, Óscar. La formación del Estado argentino. Buenos Aires: Editorial de Belgrano, (1982).

Rabinovich, Alejandro. "El fenómeno de la deserción en las guerras de la revolución e independencia del Río de la Plata: 1810-1829”, Estudios Interdisciplinarios de América Latina y el Caribe, Tel Aviv, Vol. 22 No. 1 (2011).

Rabinovich, Alejandro. Ser soldado en las guerras de independencia. La experiencia cotidiana de la tropa en el Río de la Plata, 1810-1824. Buenos Aires, Ed. Sudamericana, Colección Nudos de la historia argentina, 2013.

Ruíz Moreno, Isidro. Campañas militares argentinas. La política y la guerra. Guerra exterior y luchas internas (1865-1874). Buenos Aires: Claridad, tomo 4, 2008.

Sabato, H. "El ciudadano en armas", Entrepasados, Revista de Historia, Buenos Aires, año 12, No. 23 (2002): 149-169.

Sabato, Hilda. y Lettieri, A. (Compiladores.) La vida política. Armas, votos y voces en la Argentina del siglo XIX, Buenos Aires, FCE, 2003.

Sabato, Hilda. "Resistir la imposición, Revolución y ciudadanía y república en la Argentina de 1880", Revista de Indias, Vol. LXIX, No. 246. (2009): 159-182.

Para citar este artículo: Codesido Marzoratti, Lucas. "Los Soldados, sus Jefes y el Estado: la Construcción de la Obediencia en el Ejército de Línea (Argentina, 1862-1882)", Historia Caribe, Vol. XIV No. 35 (Julio-Diciembre 2019): 179-211. DOI: http://dx.doi.org/10.15648/hc.35.2019.7 